Research Article

\title{
Heat Shock Protein 70 (Hsp70) Level is Lower in Premature Rupture of Membrane
}

\author{
Kadar Heat Shock Protein 70 lebih Rendah pada Ketuban Pecah Dini \\ Muhammad RA Radam, Soetrisno, Supriyadi H Respati \\ Department of Obstetrics and Gynecology \\ Faculty of Medicine University of Sebelas Maret/ \\ Dr. Moewardi Hospital \\ Surakarta
}

\begin{abstract}
Objective: To prove whether the levels of Heat Shock Protein 70 (Hsp70) was lower in women experiencing premature rupture of membranes than in women with normal aterm pregnancy in order to explain occurrence of pregnancy premature rupture of membranes at termin biomolecular (Hsp70).

Method: This was an observational research and the study design was a cross-sectional study. The number of all samples was 60 women, divided into 2 groups and each group contained 30 women. Independent variable: Heat Shock Protein 70 level, Dependent variable: Premature Rupture of Membrane. Data was analyzed by $t$ test.

Result: Based on maternal characteristic on both groups, the mean levels of Hsp70 in serum of pregnant women with PROM lower (0.36) compared to normal pregnant group (3.94) and this difference was statistically significant $(p<0.001)$. Diagnostic value of the power levels of Hsp 70 in the PROM compared with normal pregnancies analysis using Receiver Operating Characteristic curve (ROC) in SPSS17.0 for Windows for by 0.833 or $83.3 \%$, it can be concluded that the diagnostic value of the PROM Hsp70 levels were good $(>50 \%)$.

Conclusion: Theme an levels of Hsp 70 in premature rupture of membranes obtained lower levels than in normal full-term pregnancy and this difference was statistically significant.

[Indones J Obstet Gynecol 2014; 2: 69-75]
\end{abstract}

Keywords: Heat Shock Protein 70, maternal stress, PROM

\begin{abstract}
Abstrak
Tujuan: Membuktikan apakah kadar Heat Shock Protein 70 (Hsp70) lebih rendah pada ketuban pecah dini dibandingkan normal ibu hamil aterm sehingga dapat menjelaskan kejadian ketuban pecah dini kehamilan aterm secara biomolekuler (Hsp70).

Metode: Penelitian observasional analitik dan desain penelitian potong lintang. Jumlah subjek penelitian adalah 60 orang, terbagi ke dalam 2 kelompok dan setiap kelompok 30 orang. Variabel independen: kadar Hsp70, Variabel dependen: KPD Hamil Aterm. Analisa statistik dengan uji t.

Hasil: Berdasarkan karakteristik ibu pada kedua kelompok penelitian, Rerata kadar Hsp70 pada serum ibu hamil dengan KPD lebih rendah $(0,36)$ dibandingkan dengan kelompok hamil normal $(3,94)$ dan perbedaan tersebut secara statistik bermakna $(p<0,001)$. Nilai kekuatan diagnostik dari kadar Hsp70 pada KPD dibandingkan dengan kehamilan normal dilakukan analisa dengan menggunakan kurva Receiver Operating Characteristic (ROC) pada SPSS 17.0 for Windows sebesar sebesar 0,833 atau 83,3\%, sehingga dapat disimpulkan nilai diagnostik kadar Hsp70 pada KPD adalah baik (>50\%).
\end{abstract}

Kesimpulan: Rerata kadar Hsp70 pada ketuban pecah dini didapatkan lebih rendah dari pada hamil aterm normal dan perbedaan ini bermakna secara statistik.

[Maj Obstet Ginekol Indones 2014; 2: 69-75]

Kata kunci: Heat Shock Protein 70, KPD, stres maternal

Correspondence: Department of Obstetrics and Gynecology Faculty of Medicine University of Sebelas Maret/ Dr. Moewardi Hospital Surakarta. Telephone.: 081329677702. Email: robby_2801@yahoo.com

\section{INTRODUCTION}

Premature rupture of membranes (PROM) is a serious problem associated with increased occurence of morbidity, maternal and fetal mortality. In aterm pregnancy, 8-10\% maternal had KPD. Some factors contributing to the maternal KPD are stress (46\%) and corioamnitis (27\%). These facts indicate that the KPD more common in maternal who received stressors either physical, psychological or social. Until now the mechanism of the KPD due primarily psychological stressors can not be explained. ${ }^{1,2}$
KPD is no sign of rupture of membranes before birth. ${ }^{3-5}$ One of the KPD due is stressful. A stress will affect the hypothalamus secretes corticotropin releasing factor (CRF) which will stimulate the anterior pituitary to release adrenocorticotropin hormone (ACTH) to stimulate the adrenal cortex hormone cortisol release. The increasing hormone cortisol will suppressed the synthesis of Heat Shock Protein (Hsp70). Including molecular chaperones Hsp70 family that has a strong contribution to immunity, as protector of the influence stressor cells. ${ }^{7-9}$ 
Increased cortisol and decreased Hsp70 would spur macrophages (monocytes) to express interleukin-12 (IL-12) and Interleukin-4 (IL-4) to stimulate $\mathrm{T}$ helper cell (Th). In the chronic psychological stress, Interferon gamma (IFN) and immunoglobulin G (IgG) increased. IFN will stimulate macrophages and target cells became attached to the Delayed Type hypersensitivity (DTH) and IgG was also attached to the target cells, followed by macrophages into the Antibody-Dependent Cellmediated Cytotoxicity (ADCC). Damaged tissue can occur through DTH and ADCC process, including the amnion and chorion, causing premature rupture. ${ }^{10-13}$ Parry's study (1998) suggests that there is an imbalance in the KPD between matrix metalloproteinases (MMP) and tissue inhibitor of matrix metalloproteinase (TIM).

This study aims to determine Hsp70 levels in KPD premature rupture of membrane and normal in aterm pregnancy.

\section{METHOD}

This study was using observational analytic crosssectional study design. Located in the Delivery Room PONEK research, Obstetrics Polyclinic Hospital Dr. Moewardi, Surakarta and Laboratory PRODIA in Surakarta and Jakarta. Research date on 1 December 2012-14 March 2013.

The sample was divided into two groups, premature rupture of membranes and normal in aterm pregnancy group. Samples the study for premature rupture of membranes group are rupture spontaneously before any signs of labor in aterm pregnancy (gestational age 37 weeks to 41 weeks).

All samples must be the inclusion and exclusion criteria. Inclusion criteria were primigravida with gestational age 37-41 weeks, for age between 2035 years old, married status, primary school-senior high school, normal and premature rupture of membranes pregnancy. Exclusion criteria were not marital status or threatened divorce, unwanted pregnancy, hypertension in pregnancy genital infections and medical disease.

This study has met the feasibility of conduct (ethical clearance) by the hospital ethics committee RSUD Dr. Moewardi Surakarta. After a survey, there are 60 women who meet the inclusion and exclusion criteria. All subjects agreed to participate in the research process as subjects. Every women is given the willingness of the subject consent form research/informed consent, were asked to read and if willing are asked to sign the sheet.

The subjects were divided into 2 groups, normal childbirth and KPD pregnancy. Before the study subjects performed blood sampling, recorded physical data such as patient height, weight, body mass index, left upper arm circumference, systolic and diastolic blood pressure. Blood was drawn from the cubital vein as much as $10 \mathrm{cc}$ and each divided $5 \mathrm{cc}$ for laboratory examination and complete blood Hsp70 (when blood sugar, SGOT, SGPT, urea, creatinine, hemoglobin levels, leukocyte numbers and total protein). Cubital venous blood as much as $5 \mathrm{cc}$ immediately accommodated in a plain tube that has been freezed to $2-8^{\circ} \mathrm{C}$ temperature. The blood is inserted into tube by the flow tube to prevent lysis of blood cells. After blood is inserted into the freeze tube, then stir them until blood tube homogen. Label written number, name, age, date of birth, sex and address of the patient. Date and time of blood sampling are listed on the label.

Tube which had been inserted into a blood-filled room $2-8^{\circ} \mathrm{C}$ temperature until frozen blood (samples should not be in contact with an icepack). Blood samples were immediately centrifuged at a speed of 3000 rotations per minute for 15 minutes. Blood serum immediately separated into the sample cup each of 0.3 cc. Serum samples given identity, name, date and type of examination. Two samples of each cup as much as $0.3 \mathrm{cc}$ of serum for Hsp70 HS examination. Serum should be stored at $-70^{\circ} \mathrm{C}$. Other of the examined samples will be stored at $20^{\circ} \mathrm{C}$ temperature as a backup sample.

How to Examinate Hsp70 HS Stress Genes: Pipette $100 \mathrm{ml}$ of buffer solvent in sinks S0 (0 ng / $\mathrm{ml}$ standard). Pipette $100 \mathrm{ml}$ standard no. 1 - no. 7 into the appropriate sinks. Pipette $100 \mathrm{ml}$ sample into the appropriate basic sinks. Close the petri dish and incubated for 2 hours further shaked at room temperature. Empty the contents of the sinks and wash by adding $400 \mathrm{ml}$ of buffer solvent in each wash sinks. The procedure was repeated up to 3 times to 4 times. After the last wash, empty sinks and tap or aspirations firmly at the top of the petri dish lint-free tissue paper to remove the remnants of washing buffer solvent. Pipette $100 \mathrm{ml}$ solvent of yellow antibody into each sinks except the blank sinks. Close the petri dish and incubated for 1 hour shaked at room temperature. Perform washing steps back as before. Add $100 \mathrm{ml}$ solution of blue conjugate in each sinks, except sinks are 
empty. Close the petri dish and incubated for 1 hour shaked at room temperature. Repeat washing as the previous step. Pipette $100 \mathrm{ml}$ substrate solvent to all sinks. Incubation for $30 \mathrm{~min}$ and shaked at room temperature. Pipette $100 \mathrm{ml}$ stop solvent into each sinks.

After making zeroreadout petri dish against a blank substrate, the optical density readout at the wavelength of $450 \mathrm{~nm}$. If the reader is not able to adjust the petri dish empty blank manually, then manually subtract the mean optical density of the blank substrate of all readout. Shaking is preferably carried out in a petri dish or equipment appropriate optical shakers at a certain speed to ensure perfect mixing of the contents of the sinks. Optimal speed for each shakers will vary and have a speed range of 120-700 rotations per minute.

The second group of data samples t test with SPSS version 17.0

\section{RESULTS}

The Characteristics Data of both study groups are shown in Table 1 below.

Table 1. The Characteristics Data for Mother in both Study Groups.

\begin{tabular}{|c|c|c|c|c|}
\hline Characteristics & $\begin{array}{l}\text { PROM } \\
\text { Mean }\end{array}$ & $\begin{array}{c}\text { Normal Pregnancy } \\
\text { Mean }\end{array}$ & Total & $\mathbf{p}$ \\
\hline Maternal age & 25.2 & 25.7 & & 0.534 \\
\hline Educational & 1.9 & 2.27 & & 0.071 \\
\hline IMT Groups & 23.14 & 25.43 & & $0.001^{*}$ \\
\hline LILA Groups & 23.36 & 25.43 & & $0.000^{*}$ \\
\hline Hsp70 level Group & 0.36 & 3.94 & & $0.000^{*}$ \\
\hline Haemoglobin & $30(50)$ & $30(50)$ & $60(100)$ & 0.899 \\
\hline Number of Leucosite & $30(50)$ & $30(50)$ & $60(100)$ & 0.116 \\
\hline Blood sugar & $30(50)$ & $30(50)$ & $60(100)$ & 0.815 \\
\hline SGOT & $30(50)$ & $30(50)$ & $60(100)$ & 0.455 \\
\hline SGPT & $30(50)$ & $30(50)$ & $60(100)$ & 0.071 \\
\hline Ureum & $30(50)$ & $30(50)$ & $60(100)$ & 0.169 \\
\hline Creatinin & $30(50)$ & $30(50)$ & $60(100)$ & 0.706 \\
\hline Total Protein & $30(50)$ & $30(50)$ & $60(100)$ & 0.180 \\
\hline Systolic & $30(50)$ & $30(50)$ & $60(100)$ & 0.850 \\
\hline Dyastolic & $30(50)$ & $30(50)$ & $60(100)$ & 0.561 \\
\hline
\end{tabular}

caption $:^{*}=p$ value $<0.05$ ( statistically significant) 
There is a data variable homogeneous and inhomogeneous. Variables are not homogeneous, namely the value of body mass index, left Upper Arm Circumference, urea and protein levels. Biological data (Hsp70 levels) also have data that is not homogeneous $(\alpha<0.05)$.

However, for variable 2 unpaired groups, equality variance is not an absolute requirement. So to see the results of using the test results on the second line (equal variances not assumed) in the table.

IMT measurements carried out as a data controller to measure Hsp70 levels in the KPD and normal pregnancy group. Looks BMI mean results as shown in Table 2.

Table 2. Distribution of BMI Mean in the Group of KPD and Normal Pregnancy Group.

\begin{tabular}{lccc}
\hline \hline Groups & Samples (N) & IMT mean & $\mathbf{p}$ \\
\hline Normal & 30 & 25.43 & $<0.001$ \\
KPD & 30 & 23.14 & \\
\hline \hline
\end{tabular}

Left upper arm circumference measurements carried out as a data controller to measure levels of Hsp70 in the KPD group and normal pregnancy group. Looks like the left LILA mean results are shown in Table 3.

Table 3. LILA Mean Distribution at KPD Group and Normal Pregnancy Group.

\begin{tabular}{lccc}
\hline \hline Groups & Samples (N) & LILA mean & $\mathbf{p}$ \\
\hline Normal & 30 & 25.53 & $<0.001$ \\
KPD & 30 & 23.36 & \\
\hline \hline
\end{tabular}

LILA left mean in maternal with lower KPD (23.36) compared to normal pregnancy group (25.53). The difference was statistically significant where $\mathrm{p}<0.001(\mathrm{p}<0.05)$ thus concluded that the lack of size LILA associated with risk of premature rupture of membranes in aterm maternal.

Measurement of Hsp70 levels serum in the KPD group and normal pregnancy groups conducted by ELISA. It appears that Hsp70 levels serum of maternal with PROM lower than normal pregnancy group.
Results on the distribution mean of Hsp70 levels serum as shown in Table 4.

The mean of Hsp70 levels serum of maternal with PROM lower (0.36) compared to normal pregnancy group (3.94) and the difference was statistically significant $(\mathrm{p}<0.001)$.

Table 4. Distribution of Mean Hsp70 Levels Serum in the KPD Group and Normal Pregnancy Group .

\begin{tabular}{lccc}
\hline \hline Groups & Samples (N) & $\begin{array}{c}\text { Mean Hsp70 } \\
\text { level }\end{array}$ & $\mathbf{p}$ \\
\hline Normal & 30 & 3.94 & $<0.001$ \\
KPD & 30 & 0.36 & \\
\hline \hline
\end{tabular}

To determine the diagnostic power value of Hsp70 levels in the KPD compared with normal pregnancy, can be analyzed using the Receiver Operating Characteristic curve (ROC) in SPSS 17.0 for Windows.

Obtained from the diagnostic value analysis of Hsp70 levels compared with 0.833 or $83.3 \%$ normal pregnancy, so it can be concluded the diagnostic value of Hsp70 levels in the KPD were good (> $50 \%)$.

Furthermore, from the ROC analysis also found the point of intersection between Hsp70 levels in normal pregnancy and KPD 2.15 with $83.3 \%$ sensitivity and $100 \%$ specificity. It means that if the obtained value $\leq 2.15 \mathrm{Hsp70}$ levels, is a sign of the KPD, with $83.3 \%$ sensitivity and $100 \%$ specificity.

\section{DISCUSSION}

This study is observational analytic cross-sectional study design to determine whether there are differences for Hsp70 levels in premature rupture of membranes in aterm pregnancy compared to normal in aterm pregnancy. The subject of this study is aterm pregnancy with premature rupture of membranes and normal pregnancy in the birth room and Polyclinic Obstetrics and Gynecology Dr. Moewardi Surakarta from December 2012 until March 2013, in accordance with the receipt of samples requirement (inclusion criteria). While the criteria for a normal pregnancy is a pregnancy where antenatal care during pregnancy until birth since there are no complications for both mother and fetus/baby. The number of samples in this study 
were 60 peoples with 30 samples distribution for the case of KPD and 30 samples for normal pregnancy.

In this study to reduce other KPD risk factors then study subjects were also measured height, weight, BMI, maternal age, gestational age, systole, diastole, when blood sugar, SGOT, SGPT, urea, creatinine, hemoglobin, leukocyte numbers and total protein.

For variable upper left arm circumference and body mass index obtained $t$ test results respectively 0.000 and $0.001(\mathrm{p}<0.05)$ that was statistically significant. This means that LILA and BMI variables have an influence on the KPD.

Assessment of nutritional status in maternal can be done by measuring LILA monitor maternal weight gain during pregnancy and the examination of specimens such as urine, feces, blood, liver and muscle were tested by laboratories. Weight gain during pregnancy is about 11.5 to $16 \mathrm{~kg}$ for women with normal prepregnancy body mass index.

In this study suggests that the nutritional status (LILA and BMI) affect the risk of PROM in aterm pregnancy. Conditions of malnutrition (poor nutrition, lack of vitamin C) supports the role of collagen in amnion membranes and korion. ${ }^{14}$ Collagen is a protein that is used for the formation of connective tissue and has a role as an anti-inflammatory compounds and anti histamin. ${ }^{15}$ Nutritional deficiency predisposes to abnormal collagen structure associated with an increased risk KPD. ${ }^{16,17}$ Improvements in the nutritional status of the mother to be planning a pregnancy is very important to prevent the occurrence of KPD.

Hsp70 level in both groups using the ELISA technique. After obtained the data mean of Hsp70 levels in the KPD (0.36) and normal pregnancy (3.94). It can be seen that there are different Hsp levels in both groups, Hsp70 levels in the KPD group lower when compared with normal pregnancy. Based on t test, CI 95\% value is between -4.58 to -2.58 . Therefore we can conclude the mean of Hsp70 levels in premature rupture of membranes is lower than the normal in aterm pregnancy and this difference was statistically significant.

Changes in serum of Hsp70 levels associated with various pathological conditions during pregnancy and Hsp70 expressed consistently in normal female reproductive tissues during pregnancy. ${ }^{18,19}$ Hsp70 levels were significantly lower in normal pregnancy than in nonpregnancy, serum Hsp70 levels increase with gestational age, while it decreased with increasing maternal age. ${ }^{20}$

Research for Hsp70 levels serum has been done on the condition of preeclampsia and preterm birth. Women with preterm labor and preeclampsia have higher Hsp70 concentrations (mean \pm standard deviation from $35.3 \pm 9.6$ mean and 24.4 $\pm 3.6 \mathrm{ng} / \mathrm{ml})$ compared with normal pregnancy $(6.1$ $\pm 0.6 \mathrm{ng} / \mathrm{ml})$ and non-pregnant women $(2.4 \pm 0.6$ $\mathrm{ng} / \mathrm{ml}) .{ }^{21} \mathrm{Hsp} 70$ levels can be found no increase in maternal with preeclampsia. This is probably due to work at an early stage Hsp70 protein cycle and has been shown to be associated with recovery, inflammation, apoptosis and hypoxemia, autoimmune diseases, organ transplantation and exposure chemotoxic. ${ }^{22}$

In accordance with the first hypothesis in this study found Hsp70 levels in premature rupture of membranes in aterm pregnancy is lower than the normal in aterm pregnany and this difference was statistically significant. High cortisol levels and low Hsp70 stimulate macrophages (monocytes) to express IL-12 and IL-4 which then stimulate Th cells. IL-12 to stimulate Th1 cells which are more dominant Th1 cells to Th2 cells. Macrophages release IL-4 that will stimulate Th cells expressing Th2 cells. IFN Th1 cells will release a more dominant over IL-10 produced by Th2 cells. IFN will stimulate macrophages and B cells into plasma cells that would be removing IgG and IgM. Macrophages that have $F_{c}$ receptors will be attached to the Fc of IgG that had been attached to the cytotrophoblast to become damaging tissue process ADCC including amnion and chorion resulting in premature rupture of membranes, ADCC process occurs because of IgG and IgM1. ${ }^{23}$ In this study, the KPD was not followed by the birth process. The Low Hsp70 levels may have an influence on labor. This is consistent with research Nogouchi (2010) which says that the increased levels of intracellular and extracellular Hsp70 normal in aterm pregnancy may play a role in the onset of labor. ${ }^{24}$

In this study, also conducted the analysis using ROC curves to determine the diagnostic power value of Hsp70 levels in the KPD compared with 
normal pregnancy. Obtained from ROC analysis of the diagnostic value of Hsp70 levels by 0.833 or $83.3 \%$, so it can be concluded the diagnostic value of Hsp70 levels in the KPD was good (> 50\%). Also obtained the intersection between the of Hsp70 levels in normal pregnancy 2,15 KPD with 83.3\% sensitivity and $100 \%$ specificity. It means that if the obtained value $\leq 2.15 \mathrm{Hsp70}$ levels, is a sign of the KPD, with $83.3 \%$ sensitivity and $100 \%$ specificity.

The weakness of this study is the limited sample size and cross-sectional research design. To see the changes and the role of Hsp70 levels in KPD needs to be done further studies with a cohort study design in order to be studied more in depth in the same individual. A cross-sectional study can not provide information that changes in Hsp70 levels plays a role in the KPD, but only provide information on the prevalence of PROM in aterm pregnancy. Further research using a sample of amniotic membrane also needs to be done to further investigate the relationship Hsp70 levels and the incidence of KPD.

\section{CONCLUSION}

In the mean of Hsp70 levels in premature rupture of membranes obtained lower levels than normal in aterm pregnancy and this difference was statistically significant.

\section{SUGGESTION}

Every maternal especially who are predisposing factors KPD Hsp70 levels checked, if there is a lower than normal levels given adequate therapy.

Further research needs to be done with samples Weight Loss and LILA are homogeneous.

\section{REFERENCES}

1. Dalono. Disertasi Mekanisme Psikoneuroimunologis Kejadian Ketuban Pecah Prematur (KPP) karena Stres atau Psikologis. Program Pascasarjana Universitas Airlangga. Surabaya. 2001

2. Latendresse G. The Interaction between Chronic Stress and Pregnancy: Preterm Birth from A Biobehavioral Perspective. J Midwifery Womens Health 2009; 54(1): 8-17.

3. Arias F. Premature Rupture Of The Membranes. In: Practical Guide To High Risk Pregnancy And Delivery. $2^{\text {nd }}$ Edition, St. Louis Missouri: Mosby Year Book 1993: 100-11.
4. Cuningham FG, Gant, Leveno, Gilstrap. Parturition; Williams Obstetrics, 22 ${ }^{\text {nd }}$ edition, Appleton and Lange New York. 2005: 176-7.

5. Handaya. Ketuban Pecah Prematur. Dalam Ilmu Kedokteran Fetomaternal edisi pertama. Himpunan Kedokteran Fetomaternal Perhimpunan Obstetri dan Ginekologi. Surabaya. 2004: 392-3

6. Soetrisno. Ekspresi heat shock protein 60, 70, 90 dan kortisol pada persalinan ibu primigravida yang mendapat psikokuratif. Disertasi Program Pascasarjana, Universitas Airlangga, Surabaya. 2009

7. Alberto JL, Macario. Sick Chaperones, Cellular Stress and Disease. NEJM. 2005; 14(353): 1489-1510.

8. Verbeke P, Fonager J, Clark BF, Rattan SI. Heat Shock respons and ageing: Mechanisms and Applications. Cell Biol Int. Denmark University of Aarhus. 2001; 25: 854-7.

9. Schlee S. A Chaperone network for the resolubilization of Protein Aggregats: Direct Interaction of clp B and DnaK. J Mol Biol. 2004; 336(1): 275-85.

10. Isenberg DA. Heat-Shock Proteins in Autoimmune Disease. Proc $4^{\text {th }}$ Asean Congress of Rheumatology. Singapore. 2003

11. Gao H, Wang Yue, Liu Xueduan, Yan. Tingfen. Global transcriptome analysis of the heat shock respons of She wanellaaneidensis. J Bacteriol. 2004; 186: 7796-803.

12. Klucken J, Shin Y, Masliah Y, Hyman. Hsp 70 Reduces alphasynucleinaggregrastion and toxicity. J Biol Chem. 2004; 279: 497-502.

13. Magrane J, Smith RC, Walsh K. Heat Shock Protein 70 participates in the neuro protective respons to intra cellularly expressed beta-amyloid in Neurons. J Neuro Sci. 2004; 24: 1700-6.

14. Pfeffer F, Casanueva E, Kamar J, Guerra A, Perichart 0 . Modulation of 72-Kilodalton Type IV Collagenase (Matrix Metalloproteinase-2) by Ascorbic Acid in Cultured Human Amnion-Derived Cells, Biol Reprod. 1998; 59: 326-9.

15. Sulistyowati S. Ketuban Pecah Dini (KPD/PROM): Kejadian, Diagnosis, Penanganan dan Komplikasi. UNS Press Solo. Surakarta. 2013

16. Parry S, Strauss JF. Premature Rupture of the Fetal Membrane. New England Med. J. 1998; 338: 663-70.

17. cLaren J, Malak TM, Bell SC. Structural characteristics of term human fetal membranes prior to labour: identification of an area of altered morphology overlying the cervix, Hum Reprod. 1999; 14 (1): 237-41.

18. Chaiworapongsa T, Erez O, Kusanovic JP, Vaisbuch E. Amniotic fluid heat shock protein 70 concentration in histologic chorioamnionitis, term and preterm parturition. J Mat Fetal Neonatal Med. 2008; 21(7): 449-61.

19. Avisar D, Alexy I, Dolja V. Class VIII Myosins Are Required for Plasmo desmatal Localization of a Closterovirus Hsp 70. Homol J Virol. 2008; 82 (6): 2836-43.

20. Molvarec A, Rigo J, Levente L. Increased serum heat shock protein 70 levels reflect systemic inflammations oxidative stress and hepatocelluler Injury In Preeclampsia. Cell Stress and Chaperone 2009; 14: 151-9.

21. Rodriguez-Dennen F, Martinez-Ocana J, Kawa-Karasik S, Villanueva-Egan L. Comparison of hemodynamic, biochemical and hematological parameters of healthy pregnant women in the third trimester of pregnancy and the active labor phase.BMC Pregnancy and Childbirth. 2011; 11(33): 1471-2393. 
22. Sulistyowati S. Ekspresi protein MHC Klas Ib (HLA-G dan Qa-2) yang rendah terhadap profil Hsp-70, VCAM-1 dan MMP-9 pada preeklampsia. Disertasi Program Pascasarjana, Universitas Airlangga, Surabaya. 2010

23. Yusrawati. Perbandingan Penanganan Aktif dan Konservatif pada Premature Rupture of the Membranes. Bagian Obstetri dan Ginekologi FK Unand/RSUP dr M Djamil. 2000: 2-10.
24. Noguchi T, Sado T, Naruse K, Shigetomi H. Evidence for Activation of toll-like receptor and receptor for advanced glycation end products in preterm birth. Mediators of Inflammation. 2010: 1-10. 